\title{
industrialização e seus impactos na urbanização do interior paulista: uma análise comparada de americana, piracicaba e santa bárbara doeste*
}

\author{
Eliana T. Terci \\ Doutora em História Social pela USP, Professora da Faculdade de Gestão e Negócios e Membro \\ do Núcleo de Pesquisa e Documentação da Universidade Metodista de Piracicaba (UNIMEP)
}

\section{RESUMO}

O século XX marca a evolução do Brasil para uma economia industrial e moderna, evo lução essa particularmente intensificada na década de 1970, com o processo de moderni zação autoritária. Sob o comando do Estado, os Planos Nacionais de Desenvolvimento (I e II PNDs) postulavam elevar o país à condição de potência mundial, implicando mudanças, como a intensificação dos fluxos migratórios e a urbanização intensa. Destacadamente, três eventos foram responsáveis pelas transfor mações urbanas mais impactantes: o esforço exportador, o Proálcool e as políticas de desconcentração industrial. O propósito do artigo é interpretar, comparativamente, os processos de industrialização e seus efeitos na urbanização de três cidades do interior do estado de São Paulo: Americana, Piracicaba e Santa Bárbara d'Oeste.

Palavras-ehave: industrialização — urbaniา zação - desenvolvimento

\section{ABSTRACT}

The century XX marks the Brazilian evolution to a industrial an modern economy. Specialty the authoritarian modernization in Brazil occurred in the 1970s. The State proposed to raise the position of the country as an economic potency in the world through the Development National Plan (I and II PNDs). It produced changes like the intensification of migratory process and intensive urbanization. Mainly three events were responsible for the most important urban changes: the exportation effort, the alcohol program (Proálcool) and the indus? trial desconcentration. This article purpose to contrast the urban experiences in these processes in three cities of the São Paulo state's inner: Americana, Piracicaba e Santa Bárbara d'Oeste.

Keywords: industrialization — urbanization — development

* Este artigo é versão expandida de trabalho apresentado na sessão "Engineering urban space and culture in twentieth-century — Rio de Janeiro and São Paulo, Brazil", no IX Congresso da Brazilian Studies Association (BRASA), realizado na Tulane University, New Orleans, Louisiana, EUA, em 27-29/03/2008. É produto das pesquisas desenvolvidas no Núcleo de Pesquisa e Documentação Regional da Universidade Metodista de Piracicaba, financiadas pelo FAP-UNIMEP, sob coordenação da autora (BILAC \&; TERCI, 2001; BILAC, et al. 2001 e TERCI et al. 2005). Submetido em outubro, 2008; aceito em julho, 2009. 


\section{Introdução}

Industrialização e urbanização constituem processos imbricados, caracterizados por traço marcadamente concentrador no Brasil, cujas origens se situam no auge do ciclo agroexportador cafeeiro das dé cadas iniciais do século XX. As condições especiais proporcionadas pela cultura cafeeira, em virtude da prioridade estabelecida pelo Estado na defesa de sua lucratividade, implicaram um padrão de industrialização concentrado no eixo Rio-São Paulo, acentuando a distribuição regionalmente desigual do emprego e da renda. Ademais, a infraestrutura criada durante aquele período foi decisiva para a manutenção do caráter concentrador do desenvolvimento. A inteᄀ gração dos mercados, que se segue a partir da Revolução de 1930, esbarrou em dificuldades decorrentes de um país de dimensões con $\neg$ tinentais, dentre as quais se destaca a custosa implantação de estrutu $\neg$ ras de transporte inter-regional, "fato que tornaria mais complexas tanto a integração do mercado nacional, como a própria desconcentração industrial" (NEGRI, 1996: 138).

Já na década de 1950, o quadro permanecia tão dramático quanto repleto de dilemas: o Grupo de Trabalho para o Desenvolvimento do Nordeste, do Plano de Metas do governo de Juscelino Kubitschek, identificava que a disparidade interna era pior que a verificada entre o centro-sul e a Europa! (GTDN, 1977). As medidas adotadas para reverter tal cenário, entretanto - sob os esforços das ações de substituição regional de importações - resultaram ineficientes, devido à forte polarização do complexo representado por São Paulo e à industrialização rápida da quele período. Consequências: enorme fluxo migratório em direção a São Paulo, acentuada concentração populacional, que resultaria na metropolização, na deterioração dos recursos naturais, na favelização, etc.

Nas décadas seguintes, já sob comando do regime autoritário, inau $\neg$ gurado pelo golpe militar de 1964, busca-se consolidar a modernização do país. O I e o II Planos Nacionais de Desenvolvimento (PNDs) postulavam completar o processo de industrialização, intensificado no governo $\mathrm{JK}$, e elevar o país à condição de potência mundial. Destacadamente, três processos foram responsáveis pelas transformações urbanas mais impactantes: o esforço exportador, resultante da intensiᄀ ficação da política de substituição de importações; o Programa Na- 
cional do Álcool (Proálcool), como resposta estratégica às crises do petróleo e às políticas de desconcentração industrial, cujas consequências foram, paradoxalmente, a intensificação dos fluxos migratórios e a urbanização intensa das grandes regiões metropolitanas do centro-sul.

A literatura especializada interpreta esse período como o ciclo da industrialização desconcentrada no Brasil (CANO, 1995; NEGRI, 1996), resultado das iniciativas governamentais visando à reversão do longo processo de concentração regional do crescimento econômico e da renda, característicos do modelo de industrialização e urbanização, em um momento em que o Estado - afora a capacidade de investi $\neg$ mento - ainda gozava de autoridade e força política para planejar, definir, regular e conduzir os rumos do desenvolvimento econômico do país.

Assim, a preocupação com o "caos urbano", resultante da industria $\neg$ lização acelerada, se traduz no capítulo IX do II PND ("Desenvolvimen to Urbano - Controle da Poluição e Prevenção do Meio Ambiente"), cujo diagnóstico atribuía à excessiva concentração industrial nas regiões metropolitanas (Rio de Janeiro e São Paulo, principalmente) a respon sabilidade pela deterioração das condições sociais e ambientais vivenciadas nessas regiões. Como estratégia de desenvolvimento e reversão do quadro, propunha "esforço político" para evitar a manutenção do crescimento excessivo dessas regiões e a expansão industrial para o in terior e o restante do país. Tal propósito seria alcançado mediante a participação articulada das três esferas de Poder Executivo - federal, estadual e municipal - observadas as suas competências específicas.

Negri (1996) destaca o Programa de Cidades Médias como exemplo das contundentes medidas do governo estadual, visando ao desenvolᄀ vimento urbano e regional de São Paulo, através de pesados investiᄀ mentos em municípios paulistas, dentre os quais Campinas, Sorocaba, São Carlos, Americana, Piracicaba e Ribeirão Preto, objetivando tornálos receptores de investimentos industriais privados.

Dessa forma, o propósito da descentralização industrial desdobra-se em virtuoso processo de interiorização da indústria paulista, resultado da diretriz maior do Plano e de sua principal contradição, qual seja, consolidar "uma sociedade industrial moderna e um modelo de eco nomia competitiva. Essa economia moderna, com seu núcleo no CentroSul (...)" (II PND, apud SOUZA, 2004: 117). Na concepção original, 
entretanto, o Programa Cidades Médias, inspirado na política urbana de tradição francesa e inglesa, tinha por estratégia a descentralização dos investimentos e do emprego, a partir de uma visão dos espaços locais integrados no território brasileiro, que combinava, estrategica $\neg$ mente, o planejamento territorial (que lidaria com a espacialização das políticas governamentais) e os Planos Diretores (que cuidariam da gestão da cidade). O Programa acabou desvirtuado, à medida que, condicionado às diretrizes econômicas, sucumbiu à visão funcional e segmentada da cidade.

Ainda que os dados para São Paulo revelem significativa alteração espacial da indústria entre 1970-90, observa-se que a Região Metropolitana de São Paulo (RMSP) perdeu aproximadamente $17 \%$ de sua participação no Valor de Transformação Industrial (VTI), caindo de 43,4\%, em 1970, para aproximadamente 26,3\%, em 1990. Paralelamente, obser vou-se crescente heterogeneidade no desenvolvimento das regiões brasileiras, despontando verdadeiras "ilhas" de produtividade. Favoreceuse, assim, o interior paulista, sobretudo os municípios médios, dotados de infraestrutura e situados nos eixos das principais vias da malha rodo $\neg$ viária estadual. Entre 1970 e 1985, enquanto a participação da RMSP no VTI estadual declinava de $74,7 \%$ para $56,6 \%$, a do interior crescia de $25,3 \%$ para $43,4 \%$. Não obstante, as agudas dificuldades da RMSP não foram satisfatoriamente resolvidas, "ao contrário, se agravaram, ao mes $\neg$ mo tempo em que a expansão industrial do interior foi acompanhada do crescimento de graves problemas urbanos que, até então, eram ca $\neg$ racterísticos da metrópole" (NEGRI, 1996:180-181).

O propósito do presente estudo consiste em interpretar, comparati vamente, as mudanças e os efeitos do processo de desconcentração in dustrial em três cidades médias do interior do estado de São Paulo: Americana, Santa Bárbara d'Oeste e Piracicaba, especialmente como esses efeitos reconfiguram o desenho urbano nas décadas de 1970 e 1980, período em que a desconcentração e o desenvolvimentismo assumem, paradoxalmente, seu auge e seu esgotamento, em razão das agudas sequelas da crise do sistema econômico internacional, que culminaria na "década perdida"'. Esses municípios estão situados no mais importante

Não é objetivo do presente artigo analisar exaustiva e especificamente esse período ou suas origens no sistema capitalista internacional e suas implicações domésticas, 
eixo rodoviário do estado - Anhanguera-Bandeirantes — interligados, na sequência, por outra importante rodovia paulista - a Luiz de Queiroz, que as coloca a menos de duas horas da capital do Estado. São, portanto, cidades incrustadas na mais dinâmica e populosa região do interior paulista. Apesar da proximidade territorial, contudo, suas origens lhes conferem formações socioeconômicas diferenciadas: Piracicaba apresenta perfil canavieiro e metal-mecânico; Americana e sua indústria têxtil receberam influência da dinâmica e pujante economia diversifi $\neg$ cada de Campinas; Santa Bárbara d'Oeste, tanto canavieira quanto têxtil, recebeu influência de ambos os complexos.

Cumpre, assim, estabelecer as relações entre o processo de industria lização e os efeitos do padrão de urbanização dele derivado. Revisitar tais experiências é bastante oportuno, especialmente neste momento em que o debate em torno do desafio urbano-regional (COUTINHO, 2003) está polarizado entre, de um lado, posições que postulam a reto $\neg$ mada do papel regulador e coordenador do Estado e, de outro, por aquelas que advogam o seu afastamento em defesa da autossuficiência alocadora de recursos, representada pelo mercado.

\section{Raízes da expansão econômica e dos padrões de urbanização}

Antes de analisar a configuração urbana mais recente — resultante inequívoca do impulso industrializante — é indispensável fazer um bre ve recuo no tempo, com o propósito de ressaltar as semelhanças e as diferenças que caracterizam os processos de evolução econômica dessas cidades.

Piracicaba deve sua formação econômica e seu desenvolvimento inicial ao ciclo açucareiro paulista do século XVIII, cuja superação pela cafeicultura manteve o município como último reduto da agroindústria canavieira (TERCI, 1997). Tal característica lhe valera o retorno vigoroso dessa tradição canavieira a partir da crise do café, na década de 1930.

porém é evidente que representa um marco tanto em termos de esgotamento do modelo desenvolvimentista quanto para a conformação urbana decorrente da crise socioeconômica que provoca. A esse respeito, ver Sola; Paulani (orgs.), 1995. 
Ainda que tenha sofrido o assédio da cafeicultura e mantido ambas as culturas, o predomínio do perfil canavieiro é seu traço sociocultural mais significativo, principalmente pela presença das usinas e dos engenhos e de toda a estrutura que os envolvia: colônias de trabalhadores, canaviais, ferrovias e fábricas de açúcar, álcool e aguardente. A demanda de equi $\neg$ pamentos fez surgir no município um importante setor metal-mecânico, tendo como embrião as Oficinas Dedini, fundadas em 1920, que fa $\neg$ vorecem a modernização das unidades açucareiras e permitem a configuração do complexo canavieiro regional.

Santa Bárbara d'Oeste também será favorecida pela formação desse complexo, visto que, do mesmo modo, teve a cultura canavieira em sua origem. No início do século XX, o município abrigava três importantes usinas de açúcar do Estado de São Paulo: Cillos², Furlan (1910) e Santa Bárbara $^{3}$ (1913), cuja produção representava 24,2\% da produção regional de Campinas e 11,3\% da estadual (NEGRI, 1988).

Americana, por sua vez, tem sua origem na formação de um povoa $\neg$ do a partir dos trabalhadores das obras de construção de um ramal da Companhia Paulista de Vias Fluviais e Férreas nas terras da Fazenda Machadinho, situada em Santa Bárbara d'Oeste. Este povoado fora reforçado com a chegada de significativo fluxo de imigrantes ameri $\neg$ canos, fugidos da Guerra de Secessão dos EUA, os quais, posterior $\neg$ mente, acessaram a terra em virtude da retaliação da Fazenda Machadinho e diversificaram a produção agrícola, além de introduzirem a indústria têxtil no município. A sorte do povoado - conhecido como Vila dos Americanos - foi selada pela instalação da Fábrica de Tecidos Carioba, pela firma Queiroz e Ralston, formada pela união de importante fazendeiro de café de Campinas e engenheiro norte-americano. Localizada ao lado da Vila, às margens do rio Piracicaba e do ribeirão Quilombo, que lhe serviriam como fontes de energia e depósitos de

\footnotetext{
Desativada em 1979, a Usina de Cillo foi fundada, ainda como engenho, em 1903, por um ex-colono do Engenho Central de Piracicaba. Em 1924, inaugurou uma estação da Cia. Paulista em suas terras, pois a família havia doado terras de sua fazenda B oa Esperança à Cia., para a passagem da ferrovia (Martins, 2007).

A outra usina existente no estado de São Paulo pertencia ao mesmo grupo francês, localizada em Rafard, na região de Piracicaba (TERCI, et al., 2005). Já desativada em 2006, as terras da Usina Santa Bárbara $\left(800 \mathrm{mil} \mathrm{m}^{2}\right)$ foram transferidas ao muni cípio; seu patrimônio, incluindo construções e entorno (cerca de $140 \mathrm{mil} \mathrm{m}^{2}$ ), foi classificado como de interesse ambiental, histórico e cultural (MARTINS, 2007).
} 
detritos industriais, também abrigava área exclusiva para a habitação dos operários, que constituiu núcleo propulsor da urbanização. O conjunto formado pelas unidades fabris e pela Vila Operária Carioba constituem o embrião do que viria a se tornar um importante complexo têxtil (MORELLI, 1997).

Vale observar "a existência de dois núcleos de povoamento: um, representado pela Vila Americana, no entorno da Estação, caracterizado pelo comércio e pela agricultura, e outro, pela Vila Operária Carioba, ligada à atividade industrial" (CARDOSO, 2004: 124). Assim, Santa Bárbara d'Oeste perde aquela referência ferroviária, com a emancipação de Americana, mas a recupera anos mais tarde (1922), quando a expansão da Cia. Paulista de Estradas de Ferro chega a Piracicaba, vindo da Ca $\neg$ pital do estado, passando por Nova Odessa e por Santa Bárbara (MAR $\neg$ TINS, 2007).

Dessa forma, as cidades em tela serão beneficiárias dos impulsos dinâmicos da economia agroexportadora, da ferrovia e da indústria tí pica do período (bens de consumo semiduráveis).

Interessante observar que, na década de 1920 - período de grande expansão da cultura cafeeira, cuja marcha, impulsionada pelas ferrovias, já havia incorporado mais da metade do estado em direção ao Rio Paraná - as cidades destacadas neste estudo, inseridas na rota cafeeira, foram beneficiárias de seus efeitos dinâmicos, mesmo que não tenham constituído centros cafeeiros de maior importância no estado. Compunham, no entanto, o embrião da rede urbana, ou do sistema paulista de cidades: todas estavam interligadas à cidade de São Paulo, localizada entre o Porto de Santos e na confluência da malha ferroviária, posição estratégica que lhes permitia concentrar parte significativa da produção industrial e dos serviços de infraestrutura e apoio à produção, articulan do os perfis dos demais núcleos urbanos (CANO, 1988).

A partir de 1930, a política de defesa do setor agroexportador cafeeiro em crise impulsiona indiretamente o crescimento industrial, ao promover a desvalorização cambial e estimular a atividade industrial interna que, por sua vez, passa a alimentar-se do próprio mercado in terno em ascensão. Por outro lado, as iniciativas governamentais, no intuito de ampliar a pauta de exportações, mediante a criação das agên cias responsáveis pela regulamentação das políticas públicas correspon $\neg$ dentes, deram grande impulso à produção sucroalcooleira. No caso de 
Piracicaba e de Santa Bárbara d'Oeste, a criação do Instituto do Açúcar e do Álcool (IAA), em 1933, potencializou sua transformação em reconhecido centro canavieiro, a despeito da imagem negativa que a mo $\neg$ nocultura da cana representava e cujas mazelas sociais não tardariam a se manifestar: proletarização e urbanização do trabalhador rural, desarา ticulação da pequena propriedade, intensificação do processo de urbanização e êxodo rural. Na década de 1930, entretanto, preocupações dessa natureza passavam ao largo, até porque ainda seriam apenas pos $\neg$ sibilidades: Piracicaba, o município canavieiro mais importante, desti nava apenas 10,65\% de sua área agrícola à cana-de-açúcar, ao passo que Santa Bárbara, mais preocupante, 32,28\% (DE CARLI, 1943).

No setor industrial, consolidou-se o complexo canavieiro com o crescimento do setor metal-mecânico e a transformação das Oficinas Dedini, na época com cerca de 80 operários, em grande grupo em? presarial metalúrgico, constituído por 6 empresas que produziam alambiques de aguardente, destilarias de álcool, acessórios para usinas, além de peças de cerâmica para consumo interno da empresa, aço e vergalhão para a construção civil, transformadores elétricos e imple mentos agrícolas. No pós-guerra, o bom desempenho da Codistil (fabricante de destilarias) e da Mausa (metalúrgica) absorviam 28,6\% do total de operários do grupo, que, em 1950, empregava mais de 1.000 trabalhadores. Levantamento realizado pela Fundação SEADE conta bilizou 250 engenhos e 3 grandes usinas - Monte Alegre, Piracicaba (Engenho Central ou Société de Sucrerie Brésiliennes) e Costa Pinto. Nos anos seguintes, foram fundadas ainda outras duas, de porte médio - Usina Modelo e Usina São Francisco do Quilombo, respectivamente em 1945 e 1947 - e ainda uma pequena: a Usina Santo Antonio, em 1952 (BILAC \& TERCI, 2001).

Em Santa Bárbara d'Oeste, a agricultura também estimulara o sur gimento de várias oficinas de conserto de máquinas e implementos agrícolas, destacando-se a Emilio Romi. Esse núcleo industrial ganha impulso na conjuntura da II Grande Guerra, evento que contribui para aumentar as dificuldades para importação de produtos industrializados,

\footnotetext{
Atualmente, resultado do processo de concentração e centralização do capital pelo qual passou o setor sucroalcooleiro, apenas a Costa Pinto, pertencente ao Grupo Cosan, permanece atuante no Município.
} 
reforçando o processo de substituição de importações. O setor metalúr gico é dinamizado a partir dos investimentos das Indústrias Romi, que contava 35 operários em meados da década de 1930 e também produzia máquinas para a lavoura, momento em que o município tinha aproxima $\neg$ damente 9 mil habitantes, 1/3 dos quais na área urbana. A partir de 1940, a empresa passa a produzir tornos mecânicos, atendendo a uma deman $\neg$ da, cujo suprimento, via importações, estava praticamente inviabilizado pela guerra; produziu também, em 1948, o primeiro trator brasileiro - o TORO . Sua maior ousadia, entretanto, foi a tentativa de produzir um veículo com $80 \%$ dos componentes nacionais, a Romi-Isetta, fruto de um convênio com a marca italiana Isetta, que já o produzia em quase toda a Europa, no pós-guerra. O projeto não vingaria, porque feria as regras estabelecidas para os veículos nacionais (PRESSUTO, 1996).

A emancipação de Americana, em 1924, torna o município centro da atividade têxtil, permitindo-lhe beneficiar-se do processo de substi tuição de importações a partir da década seguinte, podendo, assim: (i) contar com o incremento do mercado interno; (ii) sustentar sua expan $\neg$ são imediata com base na capacidade instalada; (iii) expandir-se poste riormente, adquirindo equipamentos de segunda mão no exterior; (iv) beneficiar-se sobremaneira da política protecionista de substituição de importações; e (v) circunstancialmente, beneficiar-se do incremento às exportações de tecidos, proporcionado pelos efeitos da II Guerra Mun dial, as quais chegaram a $25 \%$ da produção nacional.

Esse impulso dinâmico terá ainda dois outros efeitos (para trás), que contribuirão para a formação de um complexo têxtil regional que Carา doso (2004) identificou como uma família de cidades, incluindo, além de Americana e Santa Bárbara, outros dois municípios próximos, Nova Odessa e Sumaré. O primeiro efeito deveu-se à introdução dos fios sintéticos, inovação impactante que alterou significativamente o perfil e a espacialização da indústria têxtil de Americana, pois permitiu a reᄀ dução dos custos ao produtor, barateando o produto final e ampliando significativamente a demanda. Com essa mudança, incrementou-se um arranjo produtivo tradicional da cidade, o façonismo — espécie de produ $\neg$ ção doméstica praticada por tecelões, em teares próprios, na qualidade

Para viabilizar essa empreitada, foi constituída parceria entre André Tosello [TO] e Emílio Romi [RO] (MARTINS, 2007). 
de p;restadores de serviços terceirizados de firmas constituídas. Assim, foi selada a sorte da Carioba, cuja produção tradicional algodoeira ficou comprometida com a concorrência dos fios artificiais, especialmente o rayon. Definitivo, neste sentido, foram duas articulações empresariais de porte: em 1941, a criação da Cooperativa de Tecidos Rayon de Americana (CITRA), a partir de um grupo de façonistas e, em 1944, a instalação da Distribuidora de Tecidos de Rayon de Americana (DISTRA)."Assim, o núcleo representado pela Fábrica de Tecidos Carioba e a sua vila operária perdem importância enquanto área produtiva têxtil, passando a ter destaque as unidades produtivas espalhadas pelas outras áreas de Americana" (CARDOSO, 2004:126).

O novo arranjo produtivo e a dificuldade para importar estimulam o surgimento de um importante setor de máquinas e acessórios para o setor têxtil, a partir da iniciativa pioneira da Indústria Nardini S/A. Fundada em 1902, voltada para a fabricação de carroças e troles, passa, em 1946, a produzir teares automáticos para substituir os importados. Nas décadas seguintes, outras indústrias de pequeno e médio porte se instalarão no município, constituindo o núcleo metal-mecânico têxtil: Jayme Porteiro \& Cia. Ltda. (1950), Dide Eletrometalúrgica Ltda. (1955), Walter Porteiro (1957), Comelato e Roncato Ltda. (1958), Eletro Mecânica Ginejona Ltda. (1962), Fundição Com. Ind. Peças e Assessórios Ltda. (1969), Indústria de Máquinas Têxteis Ribeiro S/A (1970) e A. Brandilla S/A (1973).

Estudos revelam, entretanto, que era a atividade façonista que dava movimento à cidade e caracterizava a vida urbana no período: ouvia-se o barulho incessante dos teares, espalhados pela cidade em vários bar racões de pequeno porte, bem como era possível observar o movimen $\neg$ to intenso dos tecidos e dos materiais sendo transportados de um lugar para outro, através dos mais diversos meios, desde caminhões, caminho $\neg$ netes e automóveis particulares, até carrocinhas puxadas por animais (TRENTIN, 2008).

Santa Bárbara d'Oeste também será beneficiária da formação do complexo têxtil de Americana, criando as condições propícias para integrá-lo: em 1922, por iniciativa de empresários locais e da Câmara Municipal, constitui-se a Companhia Industrial de Santa Bárbara, que passaria a ser a Cia. Fiação e Tecelagem Santa Bárbara S.A. Posteriormente, entre 1933 e 1959, foram criadas 27 indústrias no setor têxtil no 
município, definindo-se - juntamente com as três usinas de açúcar e álcool e o setor metal-mecânico liderado pela Romi - seu perfil marcadamente canavieiro e têxtil por influência de suas vizinhas Piracicaba e Americana.

Os dados para o período 1939-49 revelam a pujança econômica da região de Campinas, que já alçava a segunda posição no estado e, ao final desse período, contava 4.190 estabelecimentos na indústria de transformação, os quais empregavam 68.175 pessoas, representando $12,5 \%$ do pessoal ocupado no Estado e 9,1\% do VTI estadual. Os municípios mais importantes eram Campinas (11.436 pessoas ocupadas), Jundiaí (10.451), Piracicaba (6.309), Limeira (4.538) e Americana (4.521), de modo que "esses cinco municípios concentravam $54,6 \%$ do pessoal ocupado da região e $56,1 \%$ do valor da produção industrial" (NEGRI, 1988: 84).

\section{Desenvolvimentismo e industrialização: "a sociedade em movimento"}

Em meados da década de 1950, abre-se uma nova conjuntura para a economia brasileira, que irá viabilizar a intensificação do processo de substituição de importações, uma vez que o Estado adota uma conduta mais ativa. A acirrada disputa entre as corporações estrangeiras - norteamericanas, europeias e japonesas — se estende aos mercados emergen $\neg$ tes, como o brasileiro, evidenciando-o como espaço privilegiado para a atuação das empresas multinacionais no processo de transnacionalização do capital. Nesse cenário favorável, o governo JK edita o Plano de Me $\neg$ tas e articula o tripé determinante para viabilizar a nova etapa do de $\neg$ senvolvimento, tendo à frente o próprio Estado, ao qual se agregam o capital estrangeiro e o nacional. Tendo como legenda ousada "50 anos em 5", o Plano visava dotar o país de sólido alicerce industrial, através de um conjunto de investimentos na indústria de base e em infraestrutura, a cargo do Estado, em grande medida financiados por política monetária e fiscal expansionista, além da ampliação do protecionismo ao mercado interno, através de tarifas aduaneiras e da política cambial, procurando, assim, estimular os investimentos privados, principalmente estrangeiros. O Estado passa, ainda, a fomentar o processo de industria- 
lização através do Banco Nacional de Desenvolvimento Econômico (BNDE), criado em 1952, e que passaria a ser a principal agência de fi $\neg$ nanciamento industrial, inicialmente público (indústria de base e infraestrutura), mas que não tardaria a financiar projetos do setor privado da indústria de transformação (SUZIGAN, 1988).

Essa nova orientação provoca significativas modificações na estrutu $\neg$ ra da indústria paulista. Em termos do emprego, observa-se que as empresas produtoras de bens semiduráveis vão gradativamente perden $\neg$ do importância relativa na promoção de novos empregos; as produtoras de bens intermediários - em virtude das grandes plantas industriais intensivas em capital — praticamente mantêm sua participação nos em $\neg$ pregos (1/3); já as produtoras de bens de capital e bens duráveis de consumo, por sua vez, despontam como as maiores empregadoras, pas 7 sando da modesta participação de 15,6\% dos empregos em 1956, para $34,1 \%$ em 1975, e 36,3\% em 1980. Os dados sobre Santa Bárbara d'Oeste são ilustrativos: as maiores empresas em número de operários (1975) eram a Romi (3.363), as Usinas Santa Bárbara e Cillo (cerca de 800 operários cada), a Usina Furlan (300), as têxteis exportadoras, Cia. Fiação e Tecelagem Santa Bárbara e CERMATEX, respectivamente com 367 e 300 operários (PRESSUTO, 1996).

Nessa conjuntura, Piracicaba manteve sua tendência canavieira, in crementando a formação do complexo sucroalcooleiro. O projeto desenvolvimentista do governo JK e a manutenção dos programas do IAA impulsionam o setor metal-mecânico, e, assim, o Grupo Dedini con $\neg$ quista o mercado nacional, sendo fato reconhecido amplamente entre os representantes do setor sucroalcooleiro que o empresário Mario Dedini "salvara" a indústria do açúcar, ao dar-lhe suporte tecnológico, num momento em que a capacidade importadora da economia brasi $\neg$ leira estava extremamente debilitada, tanto em virtude da conjuntura do pós-guerra, como pela queda das nossas exportações tradicionais (BILAC, 2001).

A modernização da agricultura se intensifica a partir de meados da década de 1960, com o processo de industrialização do campo brasileiᄀ ro, a consolidação dos complexos agroindustriais e a orientação modernizadora do Estado, visando à sua integração às indústrias processadoras e de insumos. Piracicaba e Santa Bárbara d'Oeste estavam em perfeita sintonia com a conjuntura e o modelo brasileiro que preconizavam a 
integração entre as agroindústrias e as atividades do setor metal-mecânico, formado pelas indústrias de equipamentos, tratores e implementos agrícolas. A propósito, a importância relativa da indústria mecânica na produção industrial da região de Campinas, que, em 1959, respondia por mais de $10 \%$, devia-se à sua peculiaridade histórica:

Essa indústria vem sendo maturada antes dos anos 50 através de tecnologia e capital nacionais, com o desenvolvimento de grupos nacionais localizados em alguns municípios da região, merecendo destaque o grupo Dedini, em Piracicaba, que se tornou o maior complexo produtor de mán quinas e equipamentos para usinas açucareiras, a Romi, em Santa Bárbara d'Oeste, concentrando sua produção na linha de máquinas-ferramentas, o mesmo acontecendo com a Nardini, em Americana, e, em Limeira, as indústrias D'Andres, Varga e Invicta (NEGRI, 1988:100).

No que se refere ao emprego de mão-de-obra agrícola, a moderni $\neg$ zação implicou a desarticulação das antigas relações de trabalho — par ceria, moradores e o colonato - a expulsão e a proletarização dos traา balhadores rurais, dando origem ao trabalhador temporário, conhecido como volante, ou boia-fria. A característica marcante dessa modernização foi seu caráter parcial, significativamente mais intenso na fase de plantio e tratos culturais do que na colheita, aspecto que acentuou o caráter sazonal do emprego, não justificando a manutenção do trabalhador permanente na propriedade, implicando na ampliação da exclusão da concentração da terra.

O quadro nacional de desigualdades era grave: a concentração fun diária, medida pelo índice de Gini — que era 0,804 em 1920 — elevou-se a 0,843 em 1950, permanecendo o mesmo em 1970; e, em 1980, atingiu 0,859 , ficando um nível abaixo da concentração absoluta!

Outra consequência igualmente dramática foi o esvaziamento do campo, que teve lugar a partir de então, com a intensificação do êxodo rural. Em 1950, 8 milhões de brasileiros deixaram o campo em direção às cidades ( $25 \%$ da população rural); em 1960, foram 14 milhões (36\% da população rural) e, em 1970, somaram 17 milhões, equivalente a cerca de $40 \%$ da população rural (MELO \& NOVAES, 1995).

Com a agricultura moderna que já ostentavam, Piracicaba e Santa Bárbara tornam-se polos de atração dessa mão-de-obra e, ao final da 
década de 1960, evidenciam-se os problemas decorrentes dessa realidade agrícola, marcada pela monocultora e pela industrialização, destacadamente o empobrecimento e a favelização dos trabalhadores não quali $\neg$ ficados, descontrole sobre o crescimento urbano, aumento da demanda por serviços públicos, etc.

A bem da verdade, esses traços são consequências do modelo de desenvolvimento e industrialização acelerada e excludente, que se man tém no regime militar a partir do golpe de 1964. Não obstante, o regiᄀ me de exceção foi fundamental para a consolidação do padrão de modernização que a economia brasileira assumira em estreita articulação com o capital internacional, numa conjuntura favorável da economia, tanto em termos da dinâmica do comércio mundial, quanto da dispo $\neg$ nibilidade de financiamento de risco e empréstimo em moeda. Foi sob os auspícios do modelo de capitalismo associado e dependente que o país vivenciou o milagre brasileiro, com um crescimento médio do PIB à taxa de $11,2 \%$ aa. entre 1968 e 1973 . O desempenho desigual dos diversos setores da economia são reveladores do caráter conservador do modelo: enquanto a taxa de crescimento da indústria de bens duráveis atingiu a média de $23,6 \%$ e a de bens de capital alcançou $18,1 \%$, no mesmo pe $\neg$ ríodo, a indústria de bens não duráveis atingia níveis relativamente in feriores, da ordem de 9,4\%; a agricultura, por sua vez, manteve seu de sempenho histórico, com taxas que não ultrapassaram 4,7\%, puxadas pelo razoável desempenho das culturas de exportação, visto que a pro $\neg$ dução de alimentos básicos caiu a taxas anuais médias de $2 \%$ aa. aproxi $\neg$ madamente (LACERDA, 2005).

O chamado esforço exportador - diretriz estabelecida para trazer diviᄀ sas e dar suporte à indústria, via importação de tecnologia - implicou o aprofundamento da modernização da agricultura com a ampliação dos complexos agroindustriais. A criação do Proálcool, em 1975, foi outro fator de grande importância, e visava criar fonte energética alter nativa ao petróleo, que havia sofrido o primeiro choque de proporções mundiais em 1973. O programa consistia, fundamentalmente, na con $\neg$ cessão de créditos e subsídios para a instalação de destilarias de álcool e beneficiou duplamente Piracicaba: i) ao privilegiar a instalação de destilarias anexas às usinas de açúcar, permitia aos antigos produtores gozar das vantagens adicionais do Programa; ii) o núcleo metal-mecânico de Piracicaba torna-se o principal fornecedor de equipamentos para usinas 
e destilarias do país. Somente em Piracicaba foram instaladas 8 destilarias entre 1975 e 1983 , e a produção de álcool salta de 18 mil litros, na safra de 1975/76, para 317 mil, na de 1985/86 (PERES, 1991).

Os efeitos do Proálcool se fizeram sentir também em termos da estrutura setorial da indústria nessa região, com o setor de bens inter mediários elevando sua participação na produção industrial de 16,6\% para $26,1 \%$, na década de 1970 , impulsionada principalmente pela in dústria química. $\mathrm{O}$ desempenho da indústria mecânica nesta década é igualmente expressivo.

A área plantada com cana (Tabela 1) sofre aumento expressivo, in tensificando ainda mais a monocultura canavieira no estado de São Paulo, principalmente nas regiões de Piracicaba e Ribeirão Preto, que constituem situações emblemáticas para ilustrar os efeitos do Proálcool no processo de agudização dessa monocultura: enquanto na primeira, região mais antiga, os municípios aqui destacados (Piracicaba e Santa Bárbara d'Oeste) sofrem uma expansão significativa, mas relativamente modesta (da ordem de $20 \%$ da área de lavoura de cana, entre 1975-85), a região de Ribeirão Preto tem a área de cana triplicada no período, conforme se observa nas tabelas abaixo. Inversamente, o efeito positivo do Proálcool pode ser confirmado no caso de Piracicaba e região, atra $\neg$ vés da observação do encolhimento da área da lavoura canavieira no período $1970-75^{\circ}$, anterior à criação do Programa, bem como sua recu peração logo em seguida (1975-85). O Grupo Dedini, de Piracicaba, foi o principal fornecedor dos equipamentos para tal expansão, tendo sido responsável por $73,9 \%$ dos projetos de destilarias negociadas no país: até 1975, havia 25, anexas às usinas e, posteriormente, foram fundadas 22, autônomas, aproveitando-se do crédito fácil e barato fornecido pelo Proálcool (PERES, 1991).

A redução da área de lavoura canavieira no período deve-se à queda das expor tações do açúcar brasileiro em razão da baixa dos preços do produto no mercado internacional. A respeito, ver Szmrecsányi, 1979. 
Tabela 1 - Área total de lavoura e área plantada com cana-de-açúcar — Estado de São Paulo e municípios de Ribeirão Preto, Piracicaba e Santa Bárbara d'Oeste

\begin{tabular}{|c|c|c|c|c|c|c|c|c|}
\hline & \multicolumn{2}{|c|}{$\begin{array}{c}1970 \\
\text { Área (mil ha) }\end{array}$} & \multicolumn{2}{|c|}{$\begin{array}{c}1975 \\
\text { Área (mil ha) }\end{array}$} & \multicolumn{2}{|c|}{$\begin{array}{c}1980 \\
\text { Área (mil ha) }\end{array}$} & \multicolumn{2}{|c|}{$\begin{array}{c}1985 \\
\text { Área (mil ha) }\end{array}$} \\
\hline & Lavoura & Cana & Lavoura & Cana & Lavoura & Cana & Lavoura & Cana \\
\hline SP & $4.735,9$ & 580,5 & $5.179,5$ & 689,5 & $5.934,0$ & $1.073,1$ & $6.524,8$ & $1.695,0$ \\
\hline $\begin{array}{l}\text { Microrregião } \\
\text { Piracicaba }\end{array}$ & 146,6 & 102,5 & 138,5 & 102,3 & 143,8 & 112,1 & 154,7 & 130,8 \\
\hline Piracicaba & 56,3 & 39,6 & 49,8 & 31,2 & 52,9 & 36,4 & 58,6 & 47,7 \\
\hline S.Bárbara & 17,5 & 9,7 & 19,1 & 15,3 & 19,1 & 13,9 & 18,3 & 14,9 \\
\hline $\begin{array}{l}\text { Microrregião } \\
\text { Ribeirão Preto }\end{array}$ & 209,4 & 83,8 & 255,7 & 100,3 & 301,6 & 161,6 & 335,4 & 207,4 \\
\hline Ribeirão Preto & 33,9 & 9,5 & 33,7 & 11,7 & 46,1 & 28,5 & 57,6 & 35,8 \\
\hline
\end{tabular}

Fonte: IBGE, Censos Agropecuários 1970-1985

Surge, assim - mediante o estímulo do Proálcool, reproduzindo o modelo concentrador de terra e renda - um segundo polo agroindustrial sucroalcooleiro, agora na região de Ribeirão Preto, que chegaria à década de 1990 como a principal região produtora do estado, num processo denominado por Pires (1996) como satelização em torno dos municípios de Ribeirão Preto (importante centro de negócios e serᄀ viços) e de Sertãozinho (centro metal-mecânico produtor de equipa $\neg$ mentos). Articulam-se e compõem-se com os municípios-sede de usinas e destilarias (Guariba, Jaboticabal, Pontal, Pradópolis, Ribeirão Preto, Santa Rosa do Viterbo, Serrana e Sertãozinho), municípios-sede de destilarias sem usinas (Barrinha, Jardinópolis, Luiz Antonio e Pitangueiras) e os exclusivamente produtores de cana-de-açúcar (Cravinhos, Dumont, Serra Azul e São Simão).

Outra observação importante, que confirma o modelo concentrador a partir do qual evolui a agroindústria canavieira, diz respeito à propor $\neg$ ção relativamente maior da expansão da área de cana-de-açúcar em relação à área de lavoura em geral, o que denota a agudização da mo $\neg$ nocultura e a formação do fenômeno denominado "mar de cana" no estado de São Paulo, com contribuição significativa das duas cidades canavieiras das quais se trata neste estudo. Os dados do censo agrope $\neg$ cuário do IBGE de 1975 revelam que a terra plantada com cana-deaçúcar absorvia cerca de $60 \%$ da área de lavoura de Piracicaba e $80 \%$ de 
Santa Bárbara d'Oeste, representando $94 \%$ da produção agrícola municipal, particularmente para esta última (CRIVELLARI, s/d). Tal expansão rápida foi possível em virtude não somente da concentração fundiária praticada pelas usinas, como também pela conversão de antigos produ $\neg$ tores de alimentos e criadores de gado em fornecedores de cana às usinas, engrossando essa antiga categoria. Ramos (1999) ressalta as im $\urcorner$ plicações negativas dessa expansão, tanto em termos da utilização de terras - pois se faz com perdas para a produção de alimentos - quanto seus impactos sobre o emprego, dimensão em que se evidencia o au mento da sazonalidade, em virtude da intensificação do uso de insumos e de equipamentos modernos.

Há, ainda, os problemas da concentração fundiária e da produção acentuada no período, detectados a partir dos dados dos censos agrope $\neg$ cuários do IBGE (1970 e 1980). Tomando-se a evolução do número de informantes e da área plantada com cana, pode-se verificar que, enquanto a área aumenta mais de três vezes no estado de São Paulo (ampliando de 580.487 ha para 1.694.994 ha), aumenta em cerca de $50 \%$ em Santa Bárbara d'Oeste (passando de 9.693 para 13.876 há) e tem leve redução em Piracicaba (de 39.579 ha para 36.452 ha), o número de in formantes foi significativamente decrescente no período: eram 15.164 e reduziram-se a 13.444 no estado de São Paulo; em Piracicaba, os 1.246 reduziram-se praticamente à metade, ou seja, 757, e, em Santa Bárbara d'Oeste, eram 228 e ficaram 86 (2,5 vezes a menos, praticamente).

Resultado dessa concentração fundiária e de um processo de mo $\neg$ dernização conservador e excludente foi o êxodo rural, que promoveu a inversão da porcentagem entre população rural e urbana a partir da década de 1960, como se observa pela Tabela 2. Caso extremo é o de Americana, cujo grau de urbanização é praticamente absoluto, caracte $\neg$ rística que também pode ser explicada por sua limitação territorial.

Especialmente em Piracicaba e em Santa Bárbara d'Oeste, o êxodo rural é consequência direta da expansão acelerada da agroindústria sucroalcooleira, cuja instalação provocou a concentração de terras, a proletarização do trabalhador rural e sua transformação num habitante urbano, promovendo, assim, um crescimento expressivo dos bairros periféricos, com concentração de população de baixa renda, cujo fenô? meno sociourbano mais notável foi o surgimento das favela $\mathrm{s}-$ pro $\neg$ blema que será abordado mais à frente. 
Tabela 2 - Taxa de urbanização: Americana, Piracicaba, Santa Bárbara d'Oeste

\begin{tabular}{l|l|l|l}
\multicolumn{1}{c}{ MUNICíPIOS } & 1970 & 1980 & 1990 \\
\hline Americana & 93,9 & 99,7 & 99,8 \\
\hline Piracicaba & 83,8 & 92,3 & 96,5 \\
\hline Santa Bárbara d'Oeste & 72,0 & 93,7 & 97,1 \\
\hline
\end{tabular}

Fonte: IBGE, Censos Demográficos, 1970/91.

Observe-se que Americana também será destino de parcela signifi $\neg$ cativa de migrantes do setor rural. Estudo sobre a origem do migrante de Americana, no período 1950-80, revela que mais da metade deles era composta de egressos do campo (RODRIGuES, 1978).

Além do Proálcool, outro fator de estímulo à industrialização do interior foi o processo de desconcentração industrial, posto em prática pelo governo durante a vigência do II PND. A partir da identificação das áreas possíveis para atração de investimentos produtivos, criaram-se polos de desenvolvimento, como o Polo Petroquímico do Nordeste, o Polo de Fertilizantes do Nordeste, além do Distrito Industrial da Zona Franca de Manaus.

No caso específico do interior paulista, o programa federal de desconcentração industrial mobilizou as prefeituras para a criação de planos e projetos de lei visando à atração das indústrias e dos projetos estadu ais e federais para suas cidades. Nessa perspectiva, e com a promessa de geração de empregos, foram criados os distritos industriais em áreas limítrofes das cidades, próximos às principais rodovias. Ansiosos para recheá-los com novas empresas e diversificar o parque industrial de suas localidades, os prefeitos promoveram um leilão de vantagens às empre $\neg$ sas candidatas, tais como isenções fiscais, infraestrutura, localização privilegiada nas principais rodovias estaduais, proximidade e acesso fa $\neg$ cilitado às fontes de matéria-prima e mão-de-obra, dentre outras.

Tabela 3 - Pessoal ocupado e Valor da Transformação Industrial na indústria de transformação no Estado de São Paulo

\begin{tabular}{c|c|c|c|c|c|c} 
& \multicolumn{3}{c}{ PESSOAL OCUPADO } & \multicolumn{3}{c}{ V T I } \\
\cline { 2 - 7 } & 1970 & 1980 & 1985 & 1970 & 1980 & 1985 \\
\hline 1. Região Metropolitana & 70,1 & 64,2 & 62,0 & 74,7 & 62,9 & 56,6 \\
\hline 1.1 Capital & 49,9 & 40,4 & 37,2 & 48,2 & 34,8 & 29,8 \\
\hline
\end{tabular}




\begin{tabular}{l|c|c|c|c|c|c}
\hline 1.2 Demais municípios & 20,2 & 23,8 & 24,8 & 26,5 & 28,1 & 26,8 \\
\hline 2. Interior & 29,9 & 35,8 & 38,0 & 25,3 & 37,1 & 43,4 \\
\hline 2.1 Litoral & 1,8 & 1,7 & 1,7 & 2,8 & 3,7 & 4,5 \\
\hline 2.2 Vale do Paraíba & 3,6 & 4,2 & 4,5 & 3,3 & 5,5 & 7,9 \\
\hline 2.3 Sorocaba & 3,6 & 4,6 & 5,2 & 2,2 & 4,1 & 4,3 \\
\hline 2.4 Campinas & 12,2 & 14,9 & 14,6 & 10,6 & 15,8 & 16,9 \\
\hline 2.5 Ribeirão Preto & 3,9 & 5,0 & 5,8 & 3,0 & 4,1 & 5,5 \\
\hline 2.6 Bauru & 1,4 & 1,5 & 1,7 & 0,9 & 1,3 & 1,4 \\
\hline 2.7 Região Oeste & 3,4 & 3,9 & 4,5 & 2,5 & 2,3 & 2,9 \\
\hline Total do Estado de São Paulo & 100 & 100 & 100 & 100 & 100 & 100 \\
\hline
\end{tabular}

Fonte: Censos Industriais de 1970/85 apud Negri, 1996.

O processo de interiorização da indústria é observado na Tabela 3: enquanto o número de pessoal ocupado e o Valor da Transformação Industrial caem na R M S P, no interior os números seguem ascendentes durante o período 1970-85. Observe-se que, na RMSP, também há perda em ambos os indicadores da capital para os demais municípios.

Saliente-se que, nesse processo de interiorização da indústria, carac $\neg$ terístico da década de 1970 , mais do que o surgimento de novas indús $\neg$ trias e grupos empresariais, o que ocorre é a transferência e/ou a insta $\neg$ lação de novas plantas e unidades industriais em centros urbanos dotados de infraestrutura, permitindo aos empresários reduzirem os "custos de aglomeração", destacadamente os relativos ao transporte de carga, ao congestionamento do tráfego urbano e, no final da década, à retomada da mobilização sindical.

Em função de tudo isso, assistimos desde a década de 1970 a um processo de instalação de plantas industriais em diversos centros urbanos interiori zados, que são, na maioria das vezes, filiais de empresas de capital nacional e estrangeiro que optaram por descentralizar suas atividades, mantendo unidades fabris na metrópole e no interior como são os casos da General Motors, Goodyear, Caterpillar, 3 M, IB M, Johnson \& Johnson, Volkswagen, Pirelli, Massey-Ferguson,Villares, entre outros (NEGRI, 1996: 191).

Esse desdobramento resulta da concepção funcionalista das cidades, adotada pelo II PND: assumidas como unidades de produção, nelas são observadas as condições que reuniam para tal fim. "As discussões em 
torno das políticas urbanas costumavam considerar o que era denomi $\neg$ nado custo de desenvolvimento da cidade e custo comparado dos dis $\neg$ tintos projetos urbanos" (SOUZA, 2004: 127). Assim, a política industrial, no contexto dessa concepção de urbano, acentuaria ainda mais os de sequilíbrios regionais do país, ainda que seu propósito fosse realizar o contrário.

Piracicaba teve seu primeiro Distrito Industrial - a unidade Inᄀ dustrial Leste-uNILESTE - concebido no embalo do crescimento acelerado no período do milagre brasileiro, mas somente consolidado na segunda metade da década de 1970. Em meio a toda sorte de acusações e suspeitas (RAZERA, 1993), sua localização privilegiada-com acesso à Rodovia Luiz de Queiroz, ligada à Via Anhanguera — foi seu principal atrativo para grandes empresas multinacionais do porte da Caterpillar, da Philips', dentre outras, as quais obviamente buscavam ampliar vantagens.

Santa Bárbara e Americana foram igualmente envolvidas na onda industrializante, impulsionadas, contudo, principalmente pelo setor têxtil, que passou a exportar grande parte de sua produção para a $\mathrm{Eu}\urcorner$ ropa, Eu A e América do Sul.

Suzigan (1989) esclarece que tal oportunidade foi criada a partir de medidas de política econômica compensatórias ao viés antiexportação do sistema protecionista, constantes de subsídios e incentivos à expor $\neg$ tação de manufaturados, tais como redução de impostos para importa $\neg$ ção de bens de capital e concessão de créditos subsidiados pelo BNDE, vale dizer: "com isso, dada a extraordinária expansão da economia mun dial até 1973, a indústria brasileira conseguiu lançar-se no mercado in ternacional sem ter realizado um esforço significativo de absorção e desenvolvimento tecnológico" (SUZIGAN, 1989: 59).

Aqui vale um registro importante: Americana constitui um exemplo emblemático do caráter predominantemente defensivo das políticas adotadas na condução do processo de substituição de importações no Brasil (Idem, 1988; 1989), cuja estratégia — assentada no protecionismo exacerbado ao mercado interno e na ausência de metas claras de desen-

Esta empresa deixou o Distrito Industrial de Piracicaba ainda no final da década de 1980 , transferindo suas atividades para a planta de Manaus, onde identificou mais vantagens fiscais e logísticas. 
volvimento científico e tecnológico - contribui para a criação de uma mentalidade protecionista do empresariado brasileiro, encarada como fim e não como meio para alcançar a eficiência competitiva ${ }^{8}$.

Dessa maneira, contando com subvenção de capital externo, a in dústria têxtil moderniza suas instalações, introduzindo a produção de fibras e tecidos sintéticos; daí resulta que, entre 1956 e 1970, a concen $\neg$ tração do ramo têxtil na região de Campinas em relação ao estado de São Paulo, salta de $10,9 \%$ para $21 \%$, graças especialmente aos municípios de Americana, Nova Odessa e Santa Bárbara d'Oeste:

Americana estava então integrada à rede econômica paulista e principal $\neg$ mente à sua capital, que tanto consumia os tecidos aqui produzidos, quanto fornecia máquinas e matéria-prima, já que a primeira fiação instala-se no município somente em 1950: a FIB R A, do grupo de origem milanesa Snia Viscosa (MORELLI, 1997: 27).

Tal "integração à rede econômica paulista", consequência do cres $\neg$ cimento relativo do setor têxtil, entretanto, deveu-se à proximidade com Campinas, principal polo de industrialização do período. Localização privilegiada foi fator fundamental para essas cidades que estavam na rota dos "corredores industriais", interligados pela extensa malha rodoviária que leva à capital do estado e conforma vertiginosa rede de escoamen $\neg$ to de mercadorias, como as Rodovias Bandeirantes, Anhanguera e Washington Luiz. Essa localização constituiu elemento facilitador para a inauguração do Distrito Industrial de Santa Bárbara d'Oeste, em 1973, o segundo deles criado no lado sudeste da cidade, visto que o primeiro, situado na divisa com Americana, apresentava problemas sérios de infraestrutura, "cuja solução demandaria concentração de inteligências e envolveria consertos que melindrariam suscetibilidades, capazes de conturbar a paz necessária entre as facções políticas" (CRIVELLARI, s/d: 55). Assim, vale a ressalva de que essa nova distribuição espacial da indústria não foi unanimemente comemorada, a julgar pelas informações disponíveis para Santa Bárbara d'Oeste. Ali, a administração pública

\footnotetext{
A prosperidade dessa indústria e a tranqüilidade do empresariado americanense se mantiveram intactos enquanto vigorou o protecionismo, mas a desregulamentação do setor e a abertura comercial da década de 1990 fizeram com que experimentasse um colapso quase terminal.
} 
vivenciou situação conflituosa, cuja solução, levada a efeito pela Comis $\neg$ são Municipal de Planejamento, foi acomodar os interesses, conce dendo incentivos para a formação de três áreas industriais distintas: o $1^{\circ}$ Distrito Industrial do Jardim Pérola, na divisa com Americana; o $2^{\circ}$ Distrito Industrial que, na década de 70 , constituía canteiro de obras das novas indústrias que se destinavam à cidade - Cutler Hammer do Brasil, Panam Plást do Brasil, entre outras — e a área descentralizada, também beneficiária dos incentivos públicos, em virtude de suas "conveniências de localização":

É o caso das Indústrias Romi S.A., que estão edificando na margem norte da Rodovia SP-304, a sudoeste da cidade, e da Cermatex Indústria de Tecidos Ltda., que está em construção à margem oeste da Avenida Interdistrital, que interliga as rodovias SP-304 e SOB-Americana, no bairro do Jerivá, na região leste do perímetro urbano (Ibidem).

Em Americana, o Distrito Industrial foi criado em 1971 como um instrumento para a viabilização do Plano Diretor de Desenvolvimento que visava ordenar a ocupação do espaço no sítio urbano, deslocando as indústrias para as zonas periféricas, sendo uma ao longo da Via Anhanguera e outra, onde se localizaria o novo distrito Industrial, na rodovia Luiz de Queiroz (MORELLI, 1997). A localização privilegiada garante que essas cidades tenham sido algumas das principais beneficiárias do processo de interiorização da indústria paulista, caso de Americana, que atraiu empresas de grande porte para o eixo da Via Anhanguera, tais como a Goodyear (pneus), Polyenka (fios), Santista (tecidos), Toyobo (tecidos e confecções). Nessas condições, "a industrialização e a urba nização se ampliam com a entrada do grande capital multinacional, e, em 1967, o IBGE aponta Americana como o mais importante centro têxtil do interior paulista, superado apenas pela Grande São Paulo" (Ibidem: 41).

Outra consequência desse processo foi o vigoroso incremento populacional, nos moldes do processo de urbanização das cidades médias brasileiras. Somente entre as décadas de 1940 e 1950, a popu lação de Americana aumenta 72,2\%, e o pessoal empregado na indús 7 tria, $87,2 \%$ - tendência que se mantém na década seguinte, quando a população cresce $108 \%$ e o pessoal ocupado na indústria, $49,3 \%$. O 
número de estabelecimentos industriais cresce 2,5 vezes no período 1940-60 (Ibidem). Os problemas desse crescimento desordenado logo começam a preocupar, principalmente os relativos à enorme prolifera $\neg$ ção de loteamentos:

A força da especulação imobiliária conduzia a implantá-los maciçamente (sic) em lugares mais lucrativos e afastados do centro, obrigando com que fossem levados melhoramentos até essas áreas distantes às custas públicas, uma vez que a legislação desobrigava os loteadores de prever quaisquer tipos de benfeitorias (Ibidem: 27).

De fato, na década de 1970, Americana e Santa Bárbara mantêm taxas elevadas de crescimento demográfico e o fluxo migratório in tenso que receberam implicou no surgimento de novos bairros na divisa entre ambos os municípios, promovendo sua conurbação. Ame ricana teve a população quase duplicada, saltando de 66 mil para 122 mil habitantes, com uma taxa de crescimento anual de 6,3\% a.a. Em Santa Bárbara d'Oeste, esse crescimento foi ainda mais expressivo: a população mais que dobrou, saltando de 31 mil para 76 mil habitantes, com um crescimento anual de 9,4\% a.a. Na mesma década, Piracicaba cresceu à taxa de 3,4\%. Em Americana e em Santa Bárbara d'Oeste, a indústria têxtil se destaca no parque industrial, sendo mais acentuado na primeira, que, já em 1988, absorvia $42,6 \%$ do pessoal ocupado no município, enquanto na segunda esse patamar era de 28,2\% (MARTINS \& GALLO, 1995).

Tal crescimento populacional amplia a demanda sobre os imóveis residenciais, elevando o preço do solo urbano, ou seja, de venda e dos aluguéis. Some-se a isso o perfil desses migrantes - em geral, de baixa escolaridade e qualificação profissional - e tem-se o fenômeno carac $\neg$ terístico do período com o processo de constituição das favelas nas periferias urbanas, reproduzindo, no interior do estado, fenômeno ca $\neg$ racterístico das capitais e das grandes regiões metropolitanas.

As cidades vão perdendo pouco a pouco seu ar caipira de outrora, adotando progressivamente o modo de vida cosmopolita da capital, com seus novos habitantes, forasteiros que chegavam de toda parte, atrás do progresso individual prometido pela modernidade. Conforme advertem Melo e Novaes (1998), o período entre 1950 e 1980 provoca anos de 
transformações assombrosas e sem paralelo no século, cuja qualificaçãosíntese é a de uma sociedade em movimento.

Observa-se, portanto, que o efeito mais imediato da interiorização da indústria foi o processo de migração, para os municípios mais indus $\neg$ trializados, de pessoas provenientes de outros estados ou de municípios vizinhos, e que define a peculiaridade da urbanização do período. Já em 1970, o censo demográfico do IBGE demonstrava que 50\% do cresciᄀ mento urbano resultava das migrações internas.

Morelli (1997) chama a atenção para a alteração da mancha urbana que esse processo acarreta para Americana, que se ajusta perfeitamen te aos demais municípios referidos, especialmente se se observarem os mapas dessas localidades: configuração tentacular, com aglomerações próximas a alguns eixos viários principais, entremeados por vazios urbanos subaproveitados. Observa ainda outro desdobramento do fenômeno da suburbanização, qual seja, a segregação da população operária, composta, na maioria, por migrantes que vêm para o muni $\neg$ cípio, atraídos pela campanha agressiva das novas empresas, na busca por mão-de-obra, e que se instalam em conjuntos habitacionais cons $\neg$ truídos na margem oposta da rodovia Anhanguera. Tais conjuntos habitacionais, viabilizados basicamente com financiamento do Banco Nacional de Habitação (BNH), apartados da cidade pela rodovia, transformam-se "na materialização de se 'estar fora da cidade', para os moradores do lugar" (Ibidem: 41). Em contrapartida, o centro histó rico, referência da origem da cidade, vai paulatinamente perdendo sua função, principalmente em virtude do processo de abandono e dete rioração do transporte ferroviário".

Aliás, ainda que a delimitação territorial assegure os limites entre Santa Bárbara d'Oeste e Americana, a questão é sempre tratada com cautela, pelo que se depreende das ações das autoridades locais — barbarenses, principalmente - dispostas a manter programas públicos nessa

\footnotetext{
O antigo prédio da Estação foi invadido na década de 1890, após desativação definiᄀ tiva do transporte de passageiros, tornando-se uma espécie de albergue alternativo, situação obviamente incômoda, que apenas se reverte a partir de 2003, quando a Prefeitura Municipal desocupa o prédio e o transforma em Centro Cultural (SILVA, 2007), ou seja, mais uma vez a solução funcionalista recai sobre aqueles a quem é negado o direito à cidade sem, entretanto, alterar a relação da população com o centro da cidade - lugar de passagem intensa, ocupação diurna e esvaziamento no período noturno.
} 
região. A propósito, a criação do Bairro da Zona Leste "tinha a intenção de fazer uma barreira para conter o avanço da cidade de Americana em território barbarense" (MARTINS, 2007:89). A julgar pelas mesmas considerações - e pela população que ali se fixou, formada basicamente por migrantes, atraídos pelas oportunidades de emprego — ali também se identificava um bairro operário que permitia a ambos os municípios compartilharem a oferta de mão-de-obra. Tal hipótese é confirmada pela imprensa barbarense:

O departamento de obras da Prefeitura Municipal de Santa Bárbara d'Oeste aprovou, no período de agosto de 1977 deste ano, somente nos bairros de Cidade Nova e Jardim Pérola, mais de 750 projetos para construção de residências, indústrias, estabelecimentos comerciais e clube social.

Os novos bairros da cidade, que já começaram a receber os melho $\neg$ ramentos públicos por parte da prefeitura barbarense estão alcançando crescimento vertiginoso numa demonstração inequívoca do progresso da cidade. O número de construções tende a aumentar nos próximos meses, pois diariamente chegam a Santa Bárbara dezenas de famílias vindas dos mais diferentes lugares do Brasil à procura de empregos em nossa cidade $\mathrm{e}$ região (Jornal d'Oeste, 31/08/1978) ${ }^{10}$.

Levantamento realizado pelo Consórcio Municipal de Promoção Social, apoiado pelos técnicos do setor de Serviços de Obras Sociais, em meados da década de 1970, identificava preocupante proliferação de barracos nas áreas periféricas da cidade. Como paliativo, propunha a criação de um núcleo de "Casas Provisórias" para transferências dessas famílias, enquanto a solução preconizada não vinha, ou seja, a construção do Núcleo Habitacional Santa Terezinha, com 129 casas, pela COHABCampinas (CRIVELLARI, s/d: 57) - mais um passo no rumo da periferização da habitação popular.

Piracicaba igualmente sofrerá os mesmos efeitos. Na década de 1970, contava 620 estabelecimentos industriais nos diversos setores alimentícios,

Para se ter uma ideia desse crescimento radial e da intencionalidade em localizar a população migrante na divisa com Americana, facilitando a integração do mercado de trabalho, Martins (2007) informa que a população dessa região, no início do século X X I , ultrapassa a casa de 80 mil habitantes, pouco menos da metade da população total de Santa Bárbara no mesmo ano. 
mecânicos, metalúrgicos e têxteis, que ocupavam, respectivamente, $25 \%$, $23 \%, 14 \%$ e $10 \%$ da mão-de-obra empregada. A imprensa local informa va que, naquele período, a cidade recebera cerca de 1.000 migrantes anualmente, sendo que, em 1977, esse número atingiu 1.337, intensifi $\neg$ cando a migração de caráter regional, desencadeada na década anterior, engrossada, posteriormente, pelos migrantes de outros estados (SIQUEI $\neg$ RA, 1993). Esses migrantes vinham atraídos pela oferta de empregos que as novas indústrias ofereciam por ocasião de suas instalações, principalᄀ mente na construção civil. Passada a fase inicial, entretanto, acabavam desempregados ou tendo como alternativa o corte da cana ou outras atividades que não exigiam maior qualificação profissional. Sua condiᄀ ção social delicada, aliada à ausência de domicílios disponíveis, condiᄀ cionava o acesso à moradia desse contingente populacional, restando-lhe estabelecer-se na periferia, na condição de inquilino de pequenas casas ou barracos, nas denominadas "áreas verdes" e demais terras públicas ou privadas desocupadas. Siqueira (1993) atribuiu o processo de favelização de Piracicaba ao "desenvolvimento não sustentado" da cidade. Segundo apurou, em 1979, registravam-se 23favelas com uma população de 10 mil pessoas e, em 1992, esses números se elevaram a 53 favelas, onde viviam 22 mil pessoas; desses moradores, $42 \%$ eram provenientes de municípios paulistas, 26\%, de Minas Gerais, 13\%, do Paraná, 9\%, da Bahia e os demais $10 \%$ eram migrantes de outros estados brasileiros.

A política habitacional então existente — circunscrita à ação do Sis $\neg$ tema Financeiro da Habitação (SFH) - foi ineficiente para atender às demandas de moradia da população brasileira, principalmente do seg $\neg$ mento de mais baixa renda, de que se trata neste estudo, composto de migrantes envolvidos em atividades econômicas nas quais prevalecia a informalidade nas relações de trabalho. Como é sabido, o sistema se apoiava no BNH, que, por sua vez, era o órgão gestor do Fundo de Garantia por Tempo de Serviço (FGTS) — principal fonte de arrecadação do banco - cujos recursos eram aplicados em programas habitacionais implantados em âmbito municipal pelas Companhias de Habitação (COHABs) ou assemelhados, que construíam os famosos conjuntos habitacionais periféricos e as "casas populares". Para ter acesso ao siste $\neg$ ma e tornar-se um mutuário, entretanto, era preciso ter um emprego fixo e ser contribuinte do FGTS, quesito que boa parte do segmento de baixa renda não cumpria, em especial os trabalhadores sazonais da la- 
voura canavieira. Some-se a isso o fato de que o sistema deveria operar com a lógica da empresa privada, ou seja, pelo princípio da autossustentação financeira, "segundo a qual investimentos sem retorno implicam a inevitabilidade da falência" (ARRETCHE, 1990: 30). Não contaria, porา tanto, com subvenções provenientes dos orçamentos públicos de quais $\neg$ quer das esferas governamentais. Assim, os custos das habitações seriam repassados aos preços e pagos pelos mutuários, a fim de evitar a falência do sistema. Seguindo a lógica da autossustentação financeira, restavam duas possibilidades para o barateamento dos custos das unidades que foram protagonizadas pelos governos municipais das cidades aqui tratadas e contribuíram para sua expansão periférica:

A) a doação do terreno e/ou infra-estrutura por parte dos estados e/ou municípios interessados na produção de conjuntos residenciais; B) a adoção por parte do B N H de um conjunto de programas caracterizados pelo abandono da proposta de oferta de conjuntos habitacionais conven $\neg$ cionais - programas Profilurb, Promorar, etc. (AR RET CHE, 1990: 30).

Assim, ainda que o SFH, no período 1964-86, tenha sido responsável por cifra nada desprezível de moradias, cerca de $25 \%$ das unidades ha bitacionais produzidas no Brasil foram construídas nos conjuntos habiᄀ tacionais segregados, formando verdadeiros bairros operários "fora" ou nos extremos da cidade, inflando a demanda por serviços públicos, como transporte, pavimentação, saneamento, postos de saúde, escolas, etc. Esses são os casos dos conjuntos habitacionais Cecap e Parque Piracicaba, respectivamente localizados às margens das rodovias do Açúcar, que liga Piracicaba a Sorocaba, e a SP 304, no trecho que liga Piracicaba a São Pedro, nas extremidades da cidade de Piracicaba; são os casos ainda dos conjuntos habitacionais de Americana, construídos do "outro lado" da rodovia Anhanguera e ainda do Santa Terezinha, de Santa Bárbara, para ficarmos nos exemplos da década de 1970. Ainda assim, certamente deixaram à margem outro contingente social expressivo, ao qual restaram alternativas como a favelização, a autoconstrução ou outras soluções paliativas.

Os dados do IBGE confirmam a precariedade do sistema habitacional para as cidades médias destacadas aqui: o censo demográfico de 1980 revela que Piracicaba e Americana registravam 1,2\% de domicílios rús- 
ticos, enquanto Santa Bárbara d'Oeste, 0,8\%. Já a partir dos dados do Censo de 1991 (Tabela 4), que contabilizam a presença de favelas, obᄀ serva-se que as mesmas absorvem 3,7\% dos domicílios de Piracicaba (o caso mais grave) e 1,1\% dos de Americana. Embora Santa Bárbara d'Oeste não registre presença de favelas, é preciso considerar o fenômeno da conurbação com Americana e, sobretudo, o critério utilizado pelo IB GE para classificar as favelas, considerados apenas os aglomerados com mais de 50 habitações, o que provavelmente subestima esse contingente.

Tabela 4 - Número de favelas, domicílios particulares permanentes, moradores e densidade domiciliar no Estado de São Paulo - 1991

\begin{tabular}{|c|c|c|c|c|c|c|c|}
\hline & & $\begin{array}{r}\text { DOMI } \\
\text { PARTIC } \\
\text { PERMA }\end{array}$ & $\begin{array}{l}\text { IOS } \\
\text { ARES } \\
\text { NTES }\end{array}$ & $\begin{array}{l}\text { MORAD } \\
\text { DOMICÍLIOS } \\
\text { PERMA }\end{array}$ & $\begin{array}{l}\text { RES EM } \\
\text { RTICULARES } \\
\text { ENTES }\end{array}$ & $\begin{array}{l}\text { DEI } \\
\text { DOI }\end{array}$ & $\begin{array}{l}\text { DADE } \\
\text { ILIAR }\end{array}$ \\
\hline & & Total & Favelas & Total & Favelas & Total & Favelas \\
\hline São Paulo & 1.269 & 8.039 .661 & 294.519 & 31.284 .067 & 1.327 .829 & 3,89 & 4,51 \\
\hline Americana & 1 & 39.936 & 449 & 152.786 & 1.870 & 3,83 & 4,16 \\
\hline Piracicaba & 24 & 72.510 & 2.691 & 282.456 & 12.353 & 3,90 & 4,59 \\
\hline
\end{tabular}

Fonte: Censo Demográfico IBGE, 1991.

Os equívocos e as distorções dessa política se devem, em grande medida, à comentada visão segmentada da cidade e à forma compartimentada como o urbano foi tratado, entendido como "a somatória da habitação, do transporte, do saneamento básico, da gestão administratiᄀ va, das finanças" (SOUZA, 2004: 114).

Habitação assume o status de mercadoria especial, tanto pela progressiva demanda da sociedade quanto pela significação político-institucional que tem no âmbito do Estado, notadamente no período do regime militar, uma vez que a indústria da construção, no Brasil, "além de ocupar até 7,2\% da população economicamente ativa (em 1980), através de empregos formais ou não, tem presença destacada no processo de in dustrialização e urbanização" (MARICATO, 1987: 15). Múltiplos inte resses, portanto, operam na construção do espaço urbano em geral e na provisão da habitação em particular, e essa relevância incide direta e ativamente na configuração das cidades nas décadas de 1970 e 1980, ou seja, o caráter matricial desse segmento tem enorme capacidade de mo $\urcorner$ vimentar a economia e interferir no padrão de urbanização: 
A população urbana brasileira passou de 52,1 milhões em 1970 para 79, 8 milhões em 1980. Aproximadamente 6 milhões de domicílios, desde barracos em favelas até apartamentos de luxo, foram criados em 10 anos nas cidades. (O SFH financiou aproximadamente 3,5 milhões em 17 anos de existência.) E o subsetor de edificações não é o mais dinâmico do setor de construção, mas sim o de construção pesada responsável pelas inúmeras hidrelétricas, portos, pontes, rodovias, ferrovias etc., que marcaram a política de grandes obras no país (Ibidem).

A intervenção do Estado, assim, obedece a muitos e complementares objetivos: ao mesmo tempo em que é suscetível aos interesses empre sariais — no sentido de privilegiar a produção habitacional para segmen $\neg$ tos sociais economicamente mais atraentes - suas agências também ensaiam inovações tecnológicas e, mesmo modestamente, enfrentam o desafio da habitação popular, além de instituírem novas exigências ao nível do planejamento urbano (legislação sobre parcelamento do solo, Planos Diretores, etc.). Tudo isso, porém, não ofusca o caráter tecnocrático e autoritário das políticas públicas de habitação e de desenvol $\neg$ vimento urbano do período, como, ademais, não esconde o insucesso e a crise pela qual passaram as principais agências e instituições corres $\neg$ pondentes, especialmente o Banco Nacional de Habitação (BNH) e o Sistema Financeiro de Habitação (SFH). Políticas erráticas, privilegiamento do setor imobiliário privado e a recessão da década de 1980, dentre outras razões, selaram o colapso definitivo de um modelo insti $\neg$ tucional de habitação que não deixou alternativas à maior parte da população urbana empobrecida que não fossem expedientes como a autoconstrução, a invasão de terras, a construção de favelas, os loteamentos irregulares - cada vez mais sob a lógica espacial da periferização. Notável é que essa tendência deixou de ser característica exclusiva das grandes cidades e regiões metropolitanas, para também redefinir o pa norama urbano das cidades médias do interior paulista.

\section{Balanço geral: cidades e não cidades}

Para concluir, é importante observar que esse cenário de segregação socioespacial é resultado direto do virtuoso crescimento econômico do 
período 1950-70, tempo em que, com efeito, as cidades se modernizaram, acompanhando os propósitos do II PND. Se concordarmos que, seguin $\neg$ do a lógica do processo de substituição de importações, esses objetivos centrais (reversão dos estrangulamentos estruturais do setor de bens de produção num projeto claramente desenvolvimentista) seriam assumidos mesmo em regime democrático (BARROS DE CASTRO \& SOUZA, 1985); ou ainda se aceitarmos a avaliação de Suzigan (1989), de que, pela primeira vez, se busca promover mudanças estruturais a partir de amplo programa de investimentos públicos e privados, é imperativo avaliar suas contradições e equívocos para que possam ser devidamente equaciona $\neg$ dos. No rol de questões que envolvem os dilemas urbanos, destaque-se a habitação, à qual se somam outros problemas de magnitude também significativa, como poluição dos recursos naturais (hídricos, sobretudo), estrangulamento da malha viária, pressão de demanda sobre os serviços essenciais, como transporte coletivo, educação e saúde, etc.

Fato é que a crença desmedida no urbanismo moderno — predomiᄀ nante no II PND e na política urbana, sob a hegemonia do pensamento estratégico — produziu um grande paradoxo: "imaginávamos, erronea mente, que o crescimento desmesurado que conhecíamos carecia de um controle e que o sistema de planejamento poderia exercer esse papel regulador". Deste modo, "vivíamos a síndrome do planejamento" (SOUZA, 2004: 119-120). Sendo assim, os problemas decorrentes não se devem ingenuamente à ausência de política urbana, mas aos seus flagrantes equívocos. Estudo apoiado por pesquisa de campo corrobora esse pro $\neg$ cesso desordenado na ocupação do espaço e ilustra o denominado caos urbano em Americana:

Como sua expansão ocorreu de forma radial, grande parte do fluxo da cidade passa por essas ruas do centro com destino a outros bairros. Como o terminal também se localiza lá, ônibus de cidades vizinhas trafegam por essas ruas estreitas e movimentadas. Forma-se assim um quadro caótico durante o dia, onde as pessoas não têm tempo nem sequer de observar o patrimônio ali instalado. Já no período noturno, poucos carros percorrem aquelas ruas, pois o centro não oferece nenhum atrativo. Todo o comércio está fechado, inclusive as igrejas e o terminal. Assim transitar pelo centro a noite tornou-se arriscado, principalmente pelas ruas do calçadão comerᄀ cial, que não possui residências e sua iluminação e mobiliários urbanos são deficientes (SILVA, 2007: 71). 
Santa Bárbara d'Oeste não apresenta cenário diferente: depois de passar por vários processos de reformas e incorporação de equipamen $\neg$ tos urbanos, sempre buscando a modernidade, a avaliação dos resultados e os recorrentes problemas da Praça Central da cidade colocam sob suspeição a eficácia dessas intervenções:

Nessa reflexão, acreditamos que as transformações espaciais ocorridas na praça, sobretudo a partir das últimas quatro décadas do século passado, apresentaram-se distantes da realidade e particularidade de seus usuários. E, ainda, que o impacto de tais transformações foi intenso a ponto de permitir apagar totalmente vestígios da história da praça, que, hoje em dia, subsiste apenas como registros esparsos, presentes na memória de seus usuários mais antigos (LINARDI, 2001:83).

Em Piracicaba, observadas diferenças de escala, a evolução urbana retrata com admirável fidelidade os grandes dilemas do processo de urbanização do país, ou seja, o crescimento da cidade reproduz os paradoxos de uma industrialização pujante, com efeitos urbanísticos devastadores — seguindo a notável oposição centro-periferia que ca $\neg$ racteriza as regiões metropolitanas - cuja realização obviamente não seria possível sem a anuência, o estímulo e também a omissão do po der público:

A partir dos anos 60, Piracicaba começa a se expandir de forma frag $\neg$ mentada e a atingir áreas distantes por intermédio de loteamentos públicos e privados. Este processo foi acompanhado pela extensão progressiva do perímetro urbano, viabilizando legalmente o espraiamento da malha da cidade e favorecendo a especulação imobiliária (...). A alta incidência de vazios urbanos potencializa a dinâmica da segregação sócio-territorial: as terras retidas para a especulação imobiliária induzem a população, em especial a de baixa renda, para regiões cada vez mais longínquas, distantes do centro urbano. Quanto mais se avança a malha urbana, ainda mais os vazios são valorizados, sendo os seus proprietários os beneficiados por este mesmo processo de urbanização: ônus para uns, benefícios a outros (Revisão do PDDP, 2003: 19).

A existência de Planos Diretores de Desenvolvimento, como nos casos de Piracicaba (1975), Americana (1970) e Santa Bárbara d'Oeste 
(1973), contudo, sequer permitiu equacionar os problemas do cresciᄀ mento econômico. Concebidos e elaborados por equipes técnicas contratadas para tal fim, em acordo com a tradição modernista e tecnocrática de planejamento, que preconcebia a cidade funcional e formosa, tais documentos, além de se terem transformado em "letra morta", desconsideravam acintosamente a cidade real. Serviam, sobretudo, para regulamentar e legitimar a ocupação do solo urbano a partir da ótica dos interesses das elites:

A exclusão urbanística, representada pela gigantesca ocupação ilegal do solo urbano, é ignorada na representação da 'cidade oficial'. Ela não cabe nas categorias do planejamento modernista/funcionalista, pois mostra semelhança com as formas urbanas pré-modernas. É possível reconhecer nas favelas semelhanças formais com os burgos medievais. Ela não cabe também no contexto do mercado imobiliário formal/legal, que corres ᄀ ponde ao urbanismo modernista. Ela não cabe ainda, de modo rigoroso, nos procedimentos dos levantamentos elaborados pela nossa maior agência de pesquisa de dados, o IBGE (MARICATO, 2000: 122).

Ao tratar dos conflitos em torno do uso do solo urbano, conduzido pelo movimento dos favelados de Piracicaba, Siqueira (1993) sugere que duas de suas principais contribuições foram: (i) admitir o problema social, representado pela existência de favelas e (ii) admitir que a questão da moradia somente poderia ser equacionada rompendo-se a lógica excludente que presidiu a ocupação e o uso do solo urbano no período ainda traduzido na concepção liberal de que ao poder público cabia, por princípio, garantir a propriedade privada. No caso de Americana, por sua vez, a elaboração do PDDI, sob a responsabilidade da Asplan (empresa contratada para tal fim) serviu apenas para atender à condição imposta pelo governo federal para a liberação de verbas (MORELLI, 1997). Vale destacar: "os superplanos são peças da mais pura tecnocracia, elaborados por especialistas de escritórios privados. Essa prática dominou o período do SERFHAU" (VILLAÇA, 2004:216), herança-padrão da qual Piracicaba também não foi exceção (DUARTE, 2003).

A constatação da crise da matriz modernista de planejamento urba $\neg$ no não implica, entretanto, incorrer no extremo oposto de ignorar sua 
efetividade em alguma medida ou de negar a necessidade de pautar o desenvolvimento urbano por um projeto de cidade, até porque, nos casos citados, os planos enfrentaram muitas barreiras para serem postos em prática. Por outro lado, a "ausência" de Estado que se seguiu, longe de produzir melhores resultados, acentuou as disparidades regionais e os problemas urbanos: o caos urbano se agrava com o tráfego lento, a falta de estacionamento, a precariedade dos transportes públicos, as favelas continuando a proliferar, os mananciais sendo mais e mais poluídos, sem contar a questão grave do lixo doméstico, que se acumula e se avoluma.

Para resumir as experiências e visualizá-las comparativamente, o Quadro I sintetiza as principais variáveis e características particulares de cada uma, bem como evidencia as similaridades.

Quadro I - Balanço Comparativo dos processos de Industrialização e Urbanização

\begin{tabular}{|c|c|c|c|}
\hline VARIÁVEL & PIRACICABA & AMERICANA & SANTA BÁRBARA D'OESTE \\
\hline $\begin{array}{c}\text { BASE } \\
\text { INDUSTRIAL }\end{array}$ & $\begin{array}{l}\text { Agroindústria } \\
\text { canavieira/Indústria } \\
\text { de bens de capital }\end{array}$ & Indústria Têxtil & $\begin{array}{l}\text { Agroindústria } \\
\text { canavieira/ } \\
\text { Indústria Têxtil }\end{array}$ \\
\hline $\begin{array}{c}\text { DISTRITO } \\
\text { INDUSTRIAL }\end{array}$ & $\begin{array}{l}\text { Sim - muito } \\
\text { importante para } \\
\text { atrair e abrigar } \\
\text { empresas. }\end{array}$ & $\begin{array}{l}\text { sim - importante para } \\
\text { atrair e abrigar empresas. }\end{array}$ & $\begin{array}{l}\text { sim - pouco } \\
\text { importante para atrair e } \\
\text { abrigar empresas. }\end{array}$ \\
\hline $\begin{array}{c}\text { PADRÃO DE } \\
\text { URBANIZAÇÃO }\end{array}$ & $\begin{array}{l}\text { Oposição centro- } \\
\text { perfiferia, grandes } \\
\text { extensões rurais }\end{array}$ & $\begin{array}{l}\text { ocupação intensiva, } \\
\text { polaridade pelo eixo da } \\
\text { Via Anhanguera e divisa } \\
\text { com santa Bárbara } \\
\text { d'Oeste }\end{array}$ & $\begin{array}{l}\text { Polaridade pela divisa } \\
\text { com Americana }\end{array}$ \\
\hline TERRITÓRIO & $\begin{array}{l}\text { Grandes proporções, } \\
\text { estimula contrastes } \\
\text { urbano-rural e } \\
\text { centro-periferia }\end{array}$ & $\begin{array}{l}\text { Restrito, limita expansão } \\
\text { econômica e urbana; } \\
\text { conurbação com s o B }\end{array}$ & $\begin{array}{l}\text { Intermediário, exprime } \\
\text { atração de Americana } \\
\text { e correspondente } \\
\text { conurbação }\end{array}$ \\
\hline $\begin{array}{c}\text { PLANO } \\
\text { DIRETOR }\end{array}$ & $\begin{array}{l}\text { sim - exigência do } \\
\text { governo federal, mas } \\
\text { muito pouco efetivo }\end{array}$ & $\begin{array}{l}\text { sim-exigência do } \\
\text { governo federal, mas } \\
\text { muito pouco efetivo }\end{array}$ & $\begin{array}{l}\text { sim-exigência do } \\
\text { governo federal, mas } \\
\text { muito pouco efetivo }\end{array}$ \\
\hline
\end{tabular}

Elaboração própria.

De maneira geral, portanto, as experiência dessas cidades médias do interior paulista confirmam a predominância dos ingredientes que ca $\neg$ racterizam a evolução urbana do país: "os intensos processos de mo dernização e urbanização no Brasil ocorreram ou sem participação popular (no regime militar) ou com participação popular controlada 
pelas elites (nos regimes populistas)". Nessas condições, a consequência mais perversa desse cenário é "a transformação das massas em cidadãos políticos modernos que participam de forma significativa nas decisões políticas e eleitorais não fazia parte de nenhuma dessas racionalidades governamentais e dos planos que geraram", de modo que, sinteticamente, "autoritarismo e profunda desigualdade social são marcas do Brasil moderno" (CALDEIRA \& HOLSTON, 2004: 233).

É nesse cenário, portanto, que se configuram "não cidades" no inteᄀ rior das cidades, ou seja, territórios desprovidos de infraestrutura urba $\neg$ na (habitação, pavimentação, saneamento, etc.) e de equipamentos sociais (escolas, postos de saúde, centros de lazer e recreação, etc.), onde se concentram pobreza e miséria, abrigando os despossuídos que marcha ram rumo a uma industrialização que não os acolheu. "Não cidades" porque são privadas precisamente dos instrumentos e dos recursos abundantes nas "áreas nobres" e que caracterizam o espaço urbano moderno, e também porque consagram a segregação em dupla dimen $\neg$ são: social e espacial. Não obstante ostentarem indicadores privilegiados em comparação às médias nacionais, Piracicaba, Americana e Santa Bárbara d'Oeste apresentam largas extensões de "não cidades", cujos contrastes marcam a paisagem urbana até o presente.

A utopia do desenvolvimento urbano se renova com o processo de democratização do país e com a inclusão do capítulo da política urbana na Constituição Federal de 1988, através dos artigos n ${ }^{\circ} 182$ e n $^{\circ} 183$,e sua regulamentação por meio do Estatuto da Cidade (Lei Federal $\mathrm{n}^{\circ}$ 10.257, de 10/07/2001). O otimismo reinante a partir desse novo marco seria justificável:

No plano normativo, a afirmação de um paradigma de novo tipo e suas balizas institucionais estabeleceram dupla renovação nas políticas públicas de desenvolvimento urbano, a saber: a exigência de formatos decisórios partici $\neg$ pativos e a disponibilidade de instrumentos transformadores orientados pelo atendimento da função social da propriedade e da cidade. Em síntese, um novo marco regulatório e um novo modelo em que forma e conteúdo se orientam para a efetiva democratização do espaço (GOULART, 2008: 1).

Vale destacar: a partir do Estatuto da Cidade, as cidades com mais de 20 mil habitantes devem elaborar ou reformular seus Planos Diretores 
com exigências participativas, sob pena de os responsáveis legais respon derem a processo impetrado pelo Ministério Público. Ainda assim, não há garantias de que tais processos assegurem o caráter participativo e transformador na gestão urbana, pois "outras variáveis devem ser levadas em conta", dentre as quais critérios políticos e institucionais, como "a conduta do governo de turno, a capacidade de organização autônoma da sociedade civil e mesmo a efetivação dos instrumentos previstos no Estatuto da Cidade que se incorporam aos respectivos planos diretores" (GOULART, 2008: 2). Novo desafio está lançado.

\section{Referências bibliográficas}

ARRETCHE, Marta. "Intervenção do estado e setor privado: o modelo brasileiro de política habitacional. Estado, Mercado e Habitação". Espaço e Debates - Revista de Estudos Regionais e Urbano, ano $\mathrm{X}, \mathrm{n}^{\circ}$ 31, 1990: 21-36.

BARROS DE CASTRO, Antonio \& SOUZA. Francisco E. P., A economia brasileira em marcha forçada. Rio de Janeiro: Paz e Terra, 1985.

BILAC, Maria Beatriz B. \& TERCI, Eliana T. Piracicaba, de Centro Policultor a Centro Canavieiro. Piracicaba: MB Editora, 2001.

CALDEIRA,Teresa P. \& HOLSTON, James. "Estado e espaço urbano no Brasil: do pla nejamento modernista às intervenções democráticas". A Participação em São Paulo. São Paulo: Ed. Unesp, 2004: 215-255.

CANO,Wilson. Desequilíbrios regionais e concentração industrial no Brasil (1930-1870). São Paulo: Global e Campinas: Unicamp, 1985.

CARDOSO, Ana M.V. "Família de Cidades: a atividade têxtil em Americana e entorno". Dissertação de Mestrado. Instituto de Geociências-UNICAMP, 2004.

COUTINHO, Luciano. "O Desafio Urbano-Regional na Construção de um Projeto de Nação". Regiões e Cidades, Cidades nas Regiões. São Paulo: Editora Unesp-Anpur, 2003: 37-55.

CRIVEllari, José M. Santa Bárbara D'Oeste: Edição Histórica. São Paulo: Editorial Focus Ltda. s/d.

DUARTE, Lígia N. R. "O processo de urbanização de Piracicaba: Estudo dos Planos Diretores - 1971-1991". Dissertação de Mestrado em Arquitetura e Urbanismo — Faculdade de Arquitetura e Urbanismo, PUCC. Campinas, 2003.

GOULART, Jefferson O. "Estatuto da Cidade e Plano Diretor Participativo: instituições contam e a política faz diferença". Paper apresentado na "Engineering urban space and culture in twentieth-century - Rio de Janeiro and São Paulo, Brazil", no IX Congresso da Brazilian Studies Association (BRASA), realizado na Tulane University, New Orleans, Louisiana, EUA, em 27-29/03/2008. 
GRUPO DE TRABALHO para o Desenvolvimento do Nordeste. "Uma política de desenvolvimento para o Nordeste". Formação Econômica do Brasil: a experiência da in dustrialização. São Paulo: Saraiva, 1977: 281-291.

LACERDA, Antonio C. et al. Economia Brasileira. 2 Ed. São Paulo: Saraiva, 2005.

LINARDI, M. Cecília Nogueira. Memória Urbana: análise espacial da praça central de Santa Bárbara d'Oeste. Piracicaba: Ed. UNIMEP, 2001.

MARICATO, Ermínia. Política Habitacional no Regime Militar. Petrópolis:Vozes, 1987. "As idéias fora do lugar e o lugar fora das idéias: planejamento urbano no Brasil". A cidade do pensamento único: desmanchando consensos. 2" Ed. Petrópolis:Vozes, 2000: 121-192.

MARTINS, José P. Soares. História de Santa Bárbara d'Oeste. Campinas: Ed. Komedi, 2007.

MARTINS, Lilia A. T. Piza \& GALlO, Zildo. "Estudo Sobre o Aproveitamento dos Recursos Naturais na Região de Piracicaba". Relatório de Pesquisa, Departamento de Economia-NPDR-FAP-UNIMEP.Piracicaba, 1995.

MELO, João Manuel C. \& NOVAES, Fernando A. "Capitalismo Tardio e Sociabilidade Moderna". História da Vida Privada no Brasil. São Paulo: Companhia das Letras, vol. 4, 1995: 559-658.

MORELLI, Daniela. "Americana em um século: a evolução urbana de uma cidade in dustrial de porte médio". Dissertação de Mestrado. Departamento de História da Arquitetura e Estética do Projeto São Paulo-FAU-USP. São Paulo, 1997.

NEGRI, Barjas. "A Interiorização da Indústria Paulista (1920-1980)". Coleção Economia Paulista - A Interiorização do Desenvolvimento Econômico do Estado de São Paulo (19201980).Vol. 1, n. 2. São Paulo: Fundação SEADE, 1988: 55-144.

Concentração e Desconcentração Industrial em São Paulo (1880-1990). Campinas: Ed. UNICAMP, 1996.

PERES, M. Thereza M. (coord.). "Estudo do Mercado de Trabalho na Agroindústria Canavieira: Região de Piracicaba". Relatório de Pesquisa, NPDR-UNIMEP. Pira cicaba, 1991.

PIRES, M. Conceição S. "O processo de urbanização e a organização do espaço em uma região canavieira: a região de Ribeirão Preto". Dissertação de Mestrado, FAU-USP. São Paulo: 1995.

POLIS - Instituto de Estudos, Formação e Assessoria em Políticas Sociais. "Revisão do Plano Diretor de Desenvolvimento de Piracicaba". Relatório I - Leitura Técnica e Participativa. Piracicaba, setembro de 2003.

PRESSUTO, André F. "A Industrialização de Santa Bárbara d'Oeste no Contexto da Interiorização da Indústria. O retrocesso a partir de 90". Monografia de conclusão de curso, Curso de Economia-FGN-UNIMEP. Piracicaba, 1996.

RAMOS, Pedro. A Agroindústria Canavieira e a Propriedade Fundiária no Brasil. São Paulo: HUCITEC, 1999.

RODRIGUES, João A. "Façonismo: um sistema de trabalho da indústria têxtil - o exemplo de Americana" Geografia das Indústrias. São Paulo, n. 6, 1978: 1-68. 
SILVA, Evelin P. "As Transformações Urbanas da Área Central de Americana". Disser tação de Mestrado, PUC-Campinas. Campinas, 2007.

SIQUEIRA, Elisabete S. "A Gestão de Projetos e a Produção da Cidadania na Associação dos Favelados de Piracicaba". Dissertação de Mestrado, PUC-SP. São Paulo, 1993.

SOLA, Lourdes \& PAULANI, Leda (orgs.). Lições da Década de 80. São Paulo: EDUSP, 1995.

SOUZA, Maria Adélia A. "O II PND e a política urbana brasileira: Uma contradição evidente". O processo de urbanização do Brasil. São Paulo: EDUSP, 2004: 111-143.

SUZIGAN, Wilson, "Estado e industrialização no Brasil". Revista de Economia Política. Vol. 8, n. 4, outubro-dezembro/1988: 5-16.

. "Reestruturação Industrial e Competitividade nos Países Avançados e nos NICs Asiáticos: Lições para o Brasil". Coleção Economia Paulista - Reestruturação In $\urcorner$ dustrial e Competitividade Internacional. São Paulo: Fundação SEADE, 1989: 7-32.

SZMRECSÁNYI,Tamás. O Planejamento da Agroindústria Canavieira do Brasil (1930-1975). São Paulo: HUCITEC-UNICAMP, 1979.

TERCI, Eliana T. et. al. Desconcentração Industrial: impactos socioeconômicos e urbanos no in terior paulista (1970-1990). Piracicaba: MB Editora, 2005.

TRENTIN, Gracieli. O Façonismo no espaço urbano de Americana. Holos, ano 24, vol. 2. 2008. Disponível em <http://www2.ifrn.edu.br/ojs/index.php/HOLOS/arti cle/.../144/142>. Acesso em 01 maio 2008.

VILLAÇA, Flávio. "Uma contribuição para a história do planejamento urbano no Braר sil", in DEÁK, Csaba \& SCHIFFER, Sueli Terezinha Ramos (orgs.), O processo de urbanização do Brasil. São Paulo: EDUSP, 2004: 169-243. 